UDC 332.1

DOI: $10.25140 / 2411-5215-2018-1(13)-105-111$

Olena Krasnonosova, Darya Mykhailenko

\title{
THEORETICAL ASPECTS OF CREATING COMMUNITIES BASED ON SUSTAINABLE SOCIAL AND ECONOMIC DEVELOPMENT OF THE REGION
}

Олена Красноносова, Дар'я Михайленко

\section{ТЕОРЕТИЧНІ АСПЕКТИ СТВОРЕННЯ ТЕРИТОРІАЛЬНИХ ГРОМАД НА ЗАСАДАХ ЗБАЛАНСОВАНОГО СОЦІАЛЬНО-ЕКОНОМІЧНОГО РОЗВИТКУ РЕГІОНУ}

\author{
Елена Красноносова, Дарья Михайленко
}

\section{ТЕОРЕТИЧЕСКИЕ АСПЕКТЫ СОЗДАНИЯ ТЕРРИТОРИАЛЬНЫХ ГРОМАД НА ОСНОВЕ СБАЛАНСИРОВАННОГО СОЦИАЛЬНО-ЭКОНОМИЧЕСКОГО РАЗВИТИЯ РЕГИОНА}

\begin{abstract}
Current socio-economic studies convince of the increase of irrational using available resources and growing social tension among the population. The key problem of social and economic development of the region is to ensure the population's welfare, including both adequate living conditions and income level. Many scientists have been involved in the formation and development of communities, namely P. Gural, A. Batanov, C. Jonassen, G Hillery, M. Baimuratov, O. Moroz, E. Ostrom, C. Tiebout. However, the accumulated practical experience and knowledge is not enough to clarify the prerequisites for the formation of communities on the principles of sustainable socio-economic development of the region. The article summarizes the approaches to forming communities on the principles of sustainable social and economic development of the region. To form communities on the principles of sustainable socio-economic development of the region, systemic reformation of the administrative and territorial structure at all the levels is required. Based on the provisions of the theory of fiscal decentralization, collective action, social self-organization, it is necessary to clearly identify the advantages of each of them and the possibility of applying provisions in domestic realities.
\end{abstract}

Keywords: community; sustainable development of the region; society; socio-economic development.

Fig.: 1. Table: 1. References: 10.

Сучасні сочіально-економічні дослідження переконують, що нерачіональне використання наявних ресурсів, сочіальне напруження серед населення посилюються. Ключовою проблемою збалансованого сочіально-економічного розвитку регіону є забезпечення добробуту населення, який включає як задоволення умовами життя, так $і$ рівень доходів. Багато науковиів досліджували проблеми формування та розвитку територіальних громад, а саме: П. Гураль, О. Батанов, C. Jonassen, G. Hillery, М. Баймуратов, О. Мороз, Е. Остром, C. Тіеbоиt. Однак практичного досвіду і знань, що накопичені, недостатньо для уточнення передумов створення територіальних громад на засадах збалансованого соиіально-економічного розвитку регіону. У статті виконано узагальнення підходів щодо створення територіальних громад на засадах збалансованого сочіально-економічного розвитку регіону. Для ӥх створення необхідно системне реформування адміністративно-територіального устрою на всіх рівнях. Ірунтуючись на положеннях теорій фіскальної децентралізації, колективних дій, соиіальної самоорганізації необхідно чітко визначити переваги кожної із них та можливість застосування положень у вітчизняних реаліях.

Ключові слова: територіальна громада; збалансований розвитку регіону; громада; сочіально-економічний розвиток.

Рис.: 1. Табл.: 1. Бібл.: 10.

Современные сочиально-экономические исследования убеждают, что нерачиональное использование существуюших ресурсов, сочиальное напряжение среди населения усиливаются. Ключевой проблемой сочиальноэкономического развития региона является обеспечение благосостояния населения, включая как обеспечение надлежащих условий жизни, так и уровень доходов. Многие ученые занимались проблемами формирования и развития территориальных громад, а именно: П. Гураль, А. Батанов, С. Jonassen, G. Hillery, М. Баймуратов, О. Мороз, Э. Остром, С. Tiebout. Однако практического опыта и накопленных знаний недостаточно для уточнения предпосылок создания территориальных громад на принципах сбалансированного сочиально-экономического развития региона. В статье выполнено обобщение подходов к созданию территориальных громад на приниипах сбалансированного сочиально-экономического развития региона. Для их создания необходимо системное реформирование административно-территориального устройства на всех уровнях. Основываясь на положениях теории фискальной децентрализации, коллективных действий, сочиальной самоорганизачии необходимо четко определить преимущества каждой из них и возможность применения положений в отечественных реалиях.

Ключевые слова: территориальная громада; сбалансированный развития региона; общество, соичальноэкономическое развитие.

Рис.: 1. Табл.: 1. Библ.: 10.

JEL Classification: O18, P25

(С Красноносова О. М., Михайленко Д. Г., 2018 
ПРОБЛЕМИ МЕНЕДЖМЕНТУ ТА РОЗВИТКУ ПРОДУКТИВНИХ СИЛ РЕГІОНУ

Problem setting. The vector of increasing territorial communities' involvement in economic and social development is inevitable. This is due to the transition from the industrial to the informative society and these changes in the socio-economic system of Ukraine. The practice of most developed countries having embarked on a similar transformation path in the early 80's shows high efficiency of this approach to solving the problems of poverty, inequality, employment, and improving the well-being and quality of life of the population in these countries. Current socio-economic studies convince of the increase of irrational using available resources and growing social tension among the population. The key problem of social and economic development of the region is to ensure the population's welfare, including both adequate living conditions and income level. One of the solutions to this problem may be the formation of communities able to provide the appropriate level of services and quality infrastructure [1].

Analysis of recent research studies and publications. A number of domestic and foreign scholars such as P. Gural, O. Batanov, C. Jonassen, G. Hillery, M. Baimuratov, O. Moroz, E. Ostrom, C. Tiebout studied in their works the issues of formation, functioning and development of communities.

Selection of previously unsettled parts of the general problem. However, the accumulated practical experience and knowledge is not enough to clarify the prerequisites for the formation of communities on the principles of sustainable socio-economic development of the region.

The object of the article is to generalize the approaches to the formation of communities on the basis of sustainable socio-economic development of the region.

Presentation of the main research material. The state of social and economic development of Ukraine has a direct dependence on the interest and ability of communities to actively engage in the development of their territories. Communities should be gradually transformed from management object to management subject and independently form their capacity. The administrativeterritorial structure requires reformation. The purpose of administrative-territorial reform is to increase the economic capacity of communities, districts and regions of Ukraine.

Problems of the administrative-territorial system often raised before experts-economists, lawyers, but everything was slowed down at the stages of elaborating draft laws and conceptual provisions. However, over the years, problems related to the management of territories were intensifying. The inability to enhance economic activity and provide favorable environment for people's livelihoods at the basic level is especially acute in villages, settlements and towns. Formation of capable territorial communities in the framework of a new administrative-territorial structure will contribute to the construction of a new model of territorial administration based on the principles of balancing national interests with the interests of the population of regions and territorial communities, decentralization, subsidiarity, widespread local self-government, capacity and autonomy of territorial communities in addressing local issues. The decentralization reform launched in 2014 aims to promote the optimal distribution of powers between local governments and executive authorities on the basis of subsidiarity and the creation of efficient territorial communities as the basic part of the administrativeterritorial system. Within the framework of the reform, fundamentally new processes of cooperation and voluntary association of territorial communities should take place in Ukraine.

It should be noted that each reform requires its scientific and methodical support, performers and a full understanding of its essence. Communities are provided with more authority and resources, which requires responsibility and competence in solving community problems from the part of local authorities.

It should be noted that common life in a certain territory and decision making are inherent in Ukrainian mentality. In the $14^{\text {th }}-17^{\text {th }}$ centuries there were the most progressive models of European self-government. However, the notion of "community" is rather new. 
ПРОБЛЕМИ МЕНЕДЖМЕНТУ ТА РОЗВИТКУ ПРОДУКТИВНИХ СИЛ РЕГІОНУ

D. Barnes highlights the following features of the community: «historically formed human community with common traditions; a set of social interactions based on family relationships, characterized by residing within the same territory, belonging to a particular social group; common, collective consumer of services, however with the demand of personified and individualized nature, with needs determining public expectations of people to meet these services; a producer of public services that to some extent already relate to the exercise of power and the participation of local civil society institutions in the life support of people; a community can influence local social life, represent the local population with its authority and grant certain powers to it» [2].

C. Jonassen [3], G. Hillery [4] provide the general idea of "community". These authors define a community as a group of people within a certain territory with common culture and social relationships identifying themselves with this group. C. Jonassen attributes the territory, population, interconnection and interdependence of community parts and division of labor in such a community, awareness of the community residents of the belonging to their community as well as the ability to make decisions on a corporate basis to community structure [3]. G. Hillery highlighted the following features of the community: the presence of the territory, general relationships and social interaction [4]. Communities have also been studied by domestic scientists such as M. Baimuratov [5] and O. Moroz [6]. The former studied legal aspects of communities formation and functioning. He highlighted the following features: territorial - joint residence of community members within a certain territory; integrative formation of a community based on the association of all the residents of a particular territory, regardless of their citizenship; intellectual - the basis of communities constituting is common interests of the residents, being of specific character and manifested in the form of a wide range of systemic individual-territorial ties; property - a community is the subject of the right of communal property; fiscal - community members are payers of local taxes and fees [5]. O. Moroz highlighted the following characteristics of the community: «a common territory of existence (which may include residence, work, possession of immovable property); common interests in solving life issues; social interaction in the process of implementing these interests; psychological self-identification of each member with the community; joint communal property; payment of communal taxes» [6].

One can agree with [9] where a community is defined as «a primary subject of local selfgovernment, consisting of individuals permanently residing in the territory concerned, solving local-level issues directly or through the municipal structures they have formed, having common communal property, owing immovable property within this territory, paying communal taxes and being connected by individual territorial bonds of a systemic nature».

In the conditions of decentralization of power relations in the state, studies of complex social systems, which operate on the basis of collective decision-making and collective action, are of relevance. This requires studying the prerequisites for the effective management of public resources at the local level.

Theories of collective action, fiscal decentralization and social self-organization can serve as the theoretical basis for the formation of communities on the principles of sustainable socio-economic development of the region (Table).

The ideology of fiscal decentralization belongs to the American economist C. Tiebout, who empirically identified the "spillover effect» - the effect of the uniform distribution of resources as a problem of redistribution of capabilities, depending on the preferences and revenues of local communities [7]. He proposes to solve this problem on the basis of the effect of the redistribution of public goods, since the capacity of each individual community depends partly on the availability of public goods in neighboring communities. 
Theoretical Basis for the Formation of Communities on the Principles of Sustainable Socio-Economic Development of the Region

\begin{tabular}{|l|c|l|}
\hline \multicolumn{1}{|c|}{ Theory } & Representative & \multicolumn{1}{c|}{ Feature } \\
\hline $\begin{array}{l}\text { Fiscal decentralization } \\
\text { theory }\end{array}$ & C. Tiebout & $\begin{array}{l}\text { Determines the effect of a uniform distribution of resources as a } \\
\text { problem of redistribution of capabilities depending on commu- } \\
\text { nities' preferences and revenues }\end{array}$ \\
\hline Collective action theory & E. Ostrom & $\begin{array}{l}\text { Communities are able to effectively manage public resources. } \\
\text { The features of each community and its ability to self- } \\
\text { government affect the quality of public using the resources. The } \\
\text { results of creating public goods depend on a well-defined set of } \\
\text { rules that arranges creating and using public goods }\end{array}$ \\
\hline $\begin{array}{l}\text { Social self-organization } \\
\text { theory }\end{array}$ & I. Prigozhin & $\begin{array}{l}\text { Determines the mechanism of self-formation and self-sufficient } \\
\text { change in social structures, thus providing a certain state of } \\
\text { organization and functioning of a complex system of society }\end{array}$ \\
\hline Free community theory & $\begin{array}{l}\text { Determines the right of the community to independent and au- } \\
\text { tonomous existence from the state authority according to its } \\
\text { nature. Just as human rights and freedoms are based on the idea } \\
\text { of natural rights, the territorial community, having been formed } \\
\text { naturally, was recognized irrespective of the state. According to } \\
\text { this theory, along with three generally recognized constitutional } \\
\text { authorities (legislative, executive and judicial) the fourth one } \\
\text { should be recognized - communal (municipal or public) power. } \\
\text { The community has the right to own and independent from the } \\
\text { central power existence by its nature, while the state does not } \\
\text { form, but only recognizes the community }\end{array}$ \\
\hline
\end{tabular}

Source: [7-9].

The ideologue of the theory of collective action is the American economist and political scientist E. Ostrom. She explored individual characteristics of various communities in the management of shared resources. E. Ostrom identifies the institutions of collective use of common property («the community») as follows: "a well-defined group of individuals, which, by defining the rules for using the resource, creates, in accordance with local conditions, long-term institutional arrangements for monitoring the use of resource, resolving conflicts, administering sanctions. Each level of government can be most effective in providing a certain set of services in the respective territory". According to E. Ostrom, it is expedient to allocate public goods of different levels: local, regional, national. She suggests identifying recipients of public goods and sources of funding for their provision. In this regard, the following provisions make sense in substantiating the directions of reforming the territorial organization of power at the local level: communities are able to effectively manage public resources; the characteristics of each community and its ability to self-government affect the quality of public use of resources; the results of the creation of public goods depend on a well-defined set of rules that organizes the creation and use of public goods. The formation of such preconditions should be based on the institutionalization of social norms of communities, which are effective not only in the formation of cooperative behavior, but also in encouraging co-operative behavior in the long run; Decentralization of power and decision making becomes possible and expedient in case all the participants in the process are interested in its implementation, the interests of users of public resources are coordinated, and the quality of life of the population improves [8].

The theory of social self-organization considers the process and mechanism of selfformation and self-sufficient change in social structures, thus providing a certain state of organization and functioning of a complex system of society. The process of self-organization is dynamic and complex. The theory of social self-organization considers social systems through the prism of the most complex open systems. The high complexity of social systems is an unconditional sign of the nonlinearity of the laws related to the dependence of states of such systems on certain external and internal factors. 
ПРОБЛЕМИ МЕНЕДЖМЕНТУ ТА РОЗВИТКУ ПРОДУКТИВНИХ СИЛ РЕГІОНУ

According to the supporters of free community theory [10], the right of the community to independently conduct its affairs is as natural and inalienable as human rights, since the community is primary in relation to the state, therefore, the latter shall respect the freedom of community self-organization.

The free community theory is based on the following principles (Fig.) [10].

The right to independence from the central government of local self-
government, and therefore the state does not form a community, but only recog-
nizes it

Fig. Principles of free community theory

«A community, according to A. de Tocqueville, "is the only association that is so wellsuited to the very human nature, since, wherever people draw together, the community forms as if by itself'. However, although the community has existed for a very long time, public freedom remains something rare and fragile ...It arises out of thin air and develops almost imperceptibly in the bowels of the semi-dense society, and only with the continuous influence of laws and customs, circumstances and especially the time it succeeds to strengthen at last». At that «it is the community that is built on the power of free peoples... Without communal institutions, a nation can form a free government, but it will never acquire the true spirit of freedom» [10].

According to the free community theory, the existence of traditions in the community serves as one of the main conditions for its successful operation. This causes the need to take into account the historical and cultural halo in the area in the formation of territorial communities.

Conclusions. To create communities on the principles of sustainable socio-economic development of the region, systemic reformation of the administrative-territorial system at all the levels is required. Based on the theories, it is necessary to clearly identify the advantages of each of them and the possibility of applying the provisions in domestic realities. Formation of communities on the basis of sustainable socio-economic development of the region leads to the unification and streamlining of the system of administrative and territorial units, increasing the efficiency of using budget funds; improving the quality and accessibility of public services to the population. 
ПРОБЛЕМИ МЕНЕДЖМЕНТУ ТА РОЗВИТКУ ПРОДУКТИВНИХ СИЛ РЕГІОНУ

\section{References}

1. Hural, P. F. (2012). Terytorialna hromada v Ukraini: reforma i rozvytok [Community in Ukraine: Reform and Developmen] Naukovyi visnyk Akademii munitsypalnoho upravlinnia. Seriia: Pravo. - Scientific Bulletin of the Academy of Municipal Governance, 1, 38-44 [in Ukrainian].

2. Batanov, O. V. (2008). Terytorialna hromada - pervynnyi subiekt munitsypalnoi vlady $\mathrm{v}$ Ukraini: poniattia ta oznaky [Community as the Primary Subject of Municipal Government in Ukraine: Notions and Features]. Visnyk Tsentralnoi vyborchoi komisii-Central Election Commission Bulletin, 2(12), 51-57. Retrieved from http://www.cvk.gov.ua/visnyk/pdf/2008_2/visnik_st_13.pdf.

3. Jonassen, C. T. (1959). Community Typology - Community Structure and Analysis. N.-Y. [s.n.].

4. Hillery, G. A. (1955). Definitions of community: areas of agreement. Rural Sociology, 20, 111-123.

5. Baimuratov, M. (2002). Pravovyi status terytorialnoi hromady v Ukraini: teoretychni ta praktychni problem [Legal Status of the Community in Ukraine: Theoretical and Practical problems]. Proceeding from Munitsypalnyi rukh: novyi etap rozvytku: materialy VII Vseukrainskykh munitsypalnykh slukhan «Munitsypalnyi rukh v Ukraini - 10 rokiv rozvytku»-Municipal movement: a new stage of development: Materials of the 7th All-Ukrainian Municipal Hearings «Municipal Movement in Ukraine - 10 Years of Development» (September 6-8, Berdiansk City) (pp. 368-371). Kyiv: Lohos [in Ukrainian].

6. Moroz, O. (2008). Terytorialna hromada: sutnist stanovlennia ta suchasni ukrainski realii [The Community: the Essence of Formation and Modern Ukrainian Realities]. Naukovyi visnyk «Demokratychne vriaduvannia» - Scientific Bulletin «Democratic Governance», 2. Retrieved from http://www.lvivacademy.com/vidavnitstvo_1/visnik2/fail/Moroz.pdf.

7. Tiebout, C. (1961). An Economic Theory of Fiscal Decentralization. Retrieved from http://www.nber.org/chapters/c2273.pdf.

8. Ostrom, E. (2010). Upravliaia obshchym: evoliutsiia instytutov kollektyvnoi deiatelnosti [Managing the Common Property: the Evolution of Collective Institutions]. Moscow: IRISEN, Mys1 [in Russian].

9. Pavluk, O. P. (2016). Terytorialna hromada yak bazova lanka administratyvnoterytorialnohoustroiu Ukrainy: problemy ta perspektyvy reformuvannia [Community as the Basic Segment of the Administrative-Territorial System of Ukraine: Reformation Problems and Prospects]. Kyiv: NISD [in Ukrainian].

10. Tokvyl A. de. (1992). Demokratyia v Ameryke [Democracy in America]. Moscow: Prohress [in Russian].

\section{Список використаних джерел}

1. Гураль П. Ф. Територіальна громада в Україні: реформа і розвиток. Науковий вісник Академії муніиипального управління. Серія : Право. 2012. Вип. 1. С. 38-44.

2. Батанов О. В. Територіальна громада - первинний суб'єкт муніципальної влади в Україні: поняття та ознаки. Вісник Центральної виборчої комісії. 2008. № 2 (12). С. 51-57. URL: http://www.cvk.gov.ua/visnyk/pdf/2008_2/visnik_st_13.pdf.

3. Jonassen C. T. Community Typology - Community Structure and Analysis. N.-Y. [s.n.], 1959.

4. Hillery G. A. Definitions of community: areas of agreement. Rural Sociology. 1955. Vol. 20. Pp. 111-123.

5. Баймуратов М. Правовий статус територіальної громади в Україні: теоретичні та практичні проблеми. Муніципальний рух: новий етап розвитку: матеріали VII Всеукраїнських муніципальних слухань «Муніципальний рух в Україні - 10 років розвитку» (6-8 вересня, Бердянськ). Київ: Логос, 2002. С. 368-371.

6. Мороз О. Ю. Територіальна громада: сутність становлення та сучасні українські реалії. Науковий вісник "Демократичне врядування». 2008. Вип. 2. URL: http://www.lvivacademy. com/vidavnitstvo_1/visnik2/fail/Moroz.pdf.

7. Tiebout C. An Economic Theory of Fiscal Decentralization. Princeton University Press. 1961. URL: http://www.nber.org/chapters/c2273.pdf.

8. Остром Э. Управляя общим: эволюция институтов коллективной деятельности: пер. с англ. Москва: ИРИСЭН, Мысль, 2010. 447 с. 
ПРОБЛЕМИ МЕНЕДЖМЕНТУ ТА РОЗВИТКУ ПРОДУКТИВНИХ СИЛ РЕГІОНУ

9. Павлюк А. П. Територіальна громада як базова ланка адміністративно-територіального устрою України: проблеми та перспективи реформування. Київ: НІСД, 2016.61 с.

10. Токвиль А. де. Демократия в Америке: пер. с фр. / предисл. Гарольда Дж. Ласки. Москва: Прогресс, 1992. 554 с.

Krasnonosova Olena - PhD in Economics, Associate Professor, Senior Researcher in the Macroeconomic Analysis and Forecasting Department of the Research Center for Industrial Development Problems of the National Academy of Sciences of Ukraine (1-a Inzhenernyi Ln., 61166 Kharkiv, Ukraine).

Красноносова Олена Миколаївна - кандидат економічних наук, доцент, старший науковий співробітник відділу макроекономічної політики та регіонального розвитку Науково-дослідного центру індустріальних проблем розвитку НАН України (пров. Інженерний, 1-а, м. Харків, 61166, Україна).

Красноносова Елена Николаевна - кандидат экономических наук, доцент, старший научный сотрудник отдела макроэкономической политики и регионального развития Научно-исследовательского центра индустриальных проблем развития НАН Украины (пер. Инженерный, 1-а, г. Харьков, 61166, Украина).

E-mail: krasnonosova@gmail.com

Mykhailenko Darya - PhD in Economics, Associate Professor, Senior Researcher in the Macroeconomic Analysis and Forecasting Department of the Research Center for Industrial Development Problems of the National Academy of Sciences of Ukraine (1-a Inzhenernyi Ln., 61166 Kharkiv, Ukraine).

Михайленко Дар'я Геннадіївна - кандидат економічних наук, доцент, старший науковий співробітник відділу макроекономічної політики та регіонального розвитку Науково-дослідного центру індустріальних проблем розвитку НАН України (пров. Інженерний, 1-а, м. Харків, 61166, Україна).

Михайленко Дарья Геннадьевна - кандидат экономических наук, доцент, старший научный сотрудник отдела макроэкономической политики и регионального развития Научно-исследовательского центра индустриальных проблем развития НАН Украины (пер. Инженерный, 1-а, г. Харьков, 61166, Украина).

E-mail: mikhailenko.dg@gmail.com.

Krasnonosova, O., Mykhailenko, D. (2018). Theoretical aspects of creating communities based on sustainable social and economic development of the region. Problems and prospects of economics and management, 1 (13), 105-111. 